\title{
Identification of pancreatic juice proteins as biomarkers of pancreatic cancer
}

\author{
JUN GAO $^{1 *}$, FENG ZHU ${ }^{1 *}$, SHUNLI LV ${ }^{1 *}$, ZHAOSHEN LI ${ }^{1}$, ZHANG LING $^{1}$, \\ YANFANG GONG ${ }^{1}, \mathrm{CHEN} \mathrm{JIE}^{1}$ and $\mathrm{LIE} \mathrm{MA}^{2}$ \\ ${ }^{1}$ Department of Gastroenterology, Changhai Hospital, ${ }^{2}$ Department of Biochemistry, Basic Medicine, \\ Second Military Medical University, Shanghai 200433, P.R. China
}

Received December 17, 2009; Accepted February 4, 2010

DOI: $10.3892 /$ or_00000812

\begin{abstract}
Pancreatic juice is a potential source of proteins associated with pancreatic cancer (PC) due to the proximity of ducts to tumor tissue. Therefore, screening of proteins in pancreatic juice from PC patients may identify new PC biomarkers. We analyzed pancreatic juice from patients with pancreatic diseases including PC, chronic pancreatitis (CP) and simple choledocholithiasis (CDS) by 2-DE. Protein spots from PC patients that changed $>2$-fold compared with both $\mathrm{CP}$ and CDS were selected and identified by mass spectrometry (MS). mRNA levels were measured by QRT-PCR in PC cell lines, PC tissues and adjacent pancreatic normal (PN) tissues. Relationships between mRNA levels in PC tissues and their clinical characteristics and promoter methylation were analyzed in PC cell lines and tissues. We found that four proteins were significantly changed in $\mathrm{PC}$ compared to $\mathrm{CP}$ and simple CDS. Two proteins were up-regulated, serine proteinase-2 (PRSS2) preproprotein and pancreatic lipaserelated protein-1 (PLRP1), and two proteins were downregulated, chymotrypsinogen $\mathrm{B}$ (CTRB) precursor and elastase 3B (ELA3B) preproprotein. In all PC cell lines, PRSS 2 mRNA levels were elevated, while PLRP 1 mRNA was detected in $4 / 5$ cell lines. ELA3B mRNA was undetectable in all cell lines, but CTRB mRNA was detected in $2 / 5$ cell lines. In PC tissues compared to PN, levels of PRSS2 mRNA were significantly higher, ELA3B significantly lower, and PLRP1 and CTRB not significantly different. Elevated PRSS2 mRNA levels correlated with high T stage. The ELA3B gene promoter had higher methylation in PC cell lines and tissues compared with PN tissues, and correlated with low ELA3B gene expression. In conclusion, comparative proteomic
\end{abstract}

Correspondence to: Dr Zhaoshen Li, Department of Gastroenterology, Changhai Hospital, Second Military Medical University, Changhai Road 174, Shanghai 200433, P.R. China

E-mail: lizhaoshen111@yahoo.com.cn

${ }^{*}$ Contributed equally

Key words: biomarker, pancreatic cancer, pancreatic juice, twodimensional gel electrophoresis, methylation analysis of pancreatic juice from PC patients is a powerful method to find new PC biomarkers. Hyperexpression of the PRSS2 gene and hypermethylation of ELA3B gene promoter were associated with $\mathrm{PC}$, raising the possibility of their application as new biomarkers in PC diagnosis and screening.

\section{Introduction}

Pancreatic cancer (PC) is an almost uniformly fatal disease, with a 5-year survival rate of less than $4 \%$. In the United States, PC is the 4th leading cause of cancer death, while in Europe it is the 6th (1). In China, it is one of the ten most fatal malignant neoplasms. The onset of PC is usually asymptomatic and without definitive clinical signs. Currently, there are no ideal markers that provide sufficient sensitivity and specificity in the clinic, making it difficult to make early diagnosis of this disease. For this reason, our previous studies have been directed towards the discovery of specific new biomarkers of PC (2-4).

Pancreatic juice contains many proteins of which may include some PC-specific proteins present from the secretion or shedding of cancer cells into the ductal lumen. Accordingly, examination of pancreatic juice in PC may be an effective way to find new PC biomarkers through screening of abundant proteins. Recently, it has been shown that comparative proteomic analysis with mass spectrometric (MS) protein identification using peptide mass fingerprints and tandem MS peptide sequencing, is an effective method to screen and identify valuable tumor markers $(5,6)$.

In the present study, pancreatic juice from PC patients, chronic pancreatitis (CP) patients, and simple choledocholithiasis (CDS) patients was collected. The pancreatic juice from all patients in each group was pooled together, and an equal amount of total protein from each group analyzed by 2-DE. Four proteins that changed more than 2-fold in PC compared to controls were identified and validated.

\section{Materials and methods}

Pancreatic juice, $P C$ cell lines and tissues. The pancreatic juice samples from $8 \mathrm{PC}, 10 \mathrm{CP}$ and 6 simple CDS patients at the Shanghai Changhai Hospital of Second Military Medical University were collected during endoscopic retrograde cholangiopancreatography (ERCP), and immediately stored 
Table I. Clinicopathological characteristics of PC patients.

\begin{tabular}{|c|c|c|c|c|c|c|c|c|}
\hline $\begin{array}{l}\text { No. of } \\
\text { patients }\end{array}$ & Gender & Age & $\mathrm{T}$ & $\mathrm{N}$ & M & Grading & $\begin{array}{l}\text { Tumor } \\
\text { location }\end{array}$ & Diagnostic method \\
\hline PC no. 1 & M & 72 & 2 & 1 & 0 & IIb & Head & Clinical + cytological diagnosis \\
\hline PC no. 2 & M & 74 & 3 & 0 & 0 & IIa & Tail & Clinical + cytological diagnosis \\
\hline PC no. 3 & $\mathrm{~F}$ & 60 & 3 & 1 & 0 & $\mathrm{IIb}$ & Head & Clinical + cytological diagnosis \\
\hline PC no. 4 & $\mathrm{~F}$ & 63 & 3 & 0 & 0 & IIa & Body & Clinical + cytological diagnosis \\
\hline PC no. 5 & M & 51 & 2 & 0 & 0 & $\mathrm{Ib}$ & Body & Clinical + cytological diagnosis \\
\hline PC no. 6 & M & 52 & 2 & 0 & 0 & $\mathrm{Ib}$ & Tail & Clinical + cytological diagnosis \\
\hline PC no. 7 & $\mathrm{~F}$ & 54 & 3 & 1 & 0 & IIb & Head & Clinical + cytological diagnosis \\
\hline PC no. 8 & $\mathrm{~F}$ & 64 & 3 & 1 & 0 & $\mathrm{IIb}$ & Head & Clinical + cytological diagnosis \\
\hline
\end{tabular}

at $-80^{\circ} \mathrm{C}$. The study was approved by the Institutional Review Board, and signed informed consent was obtained from all participants. The diagnosis of the PC was verified by the cytological examination of the pancreas specimens obtained by endoscopic ultrasound-guided fine-needle aspiration. The $\mathrm{CP}$ and CDS diagnoses were based on clinical information from B-mode ultrasonography and CT detection or cytological methods. The clinical data of the PC patients is summarized in Table I. Before electrophoresis, the samples were centrifuged at $14,000 \mathrm{rpm}$ for $15 \mathrm{~min}$ at $4^{\circ} \mathrm{C}$ to remove debris. Protein concentrations were measured using the Bradford Assay according to the manufacturer's protocol (Bio-Rad Laboratories, Hercules, CA). Pancreatic juice from all patients in each group was pooled together to provide equal amounts of total protein from each group. A suitable volume of pooled pancreatic juice together with $200 \mu \mathrm{g}$ of total protein was suspended in ice-cold TCA in acetone and kept at $-20^{\circ} \mathrm{C}$ overnight for protein precipitation. Following centrifugation at $14,000 \mathrm{rpm}$ for $15 \mathrm{~min}$ at $4^{\circ} \mathrm{C}$, the supernatant was discarded, and the protein pellet was washed in ice-cold acetone containing $0.2 \%$ DTT, dried under a vacuum, and then solubilized in $350 \mu \mathrm{l}$ of lysis buffer containing $8 \mathrm{M}$ urea, $2 \%$ CHAPS, 18 mM DTT, $0.5 \%$ IPG buffer, $0.002 \%$ bromophenol blue and $1 \mathrm{mmol} / \mathrm{l}$ phenylmethyl sulfonylfluoride.

PC cell lines (SW1990, Panc-1, CFPAC and BXPC3) were purchased from the American Type Culture Collection, except for PaTu8988, which was obtained from Dr H.P. Elsasser (Phillips University, Marburg, Germany). Cells were grown in DMEM medium (Life Technologies Inc., Rockville, MD) supplemented with $10 \%$ fetal bovine serum and incubated in $5 \% \mathrm{CO}_{2}$ at $37^{\circ} \mathrm{C}$.

Thirty PC tissues and their corresponding adjacent pancreatic normal (PN) tissues confirmed according to $\mathrm{HE}$ staining of frozen sections, were collected immediately after pancreatic surgical resection. Samples were selected from only those tissues in which the proportion of tumor cells was over $70 \%$, and their corresponding adjacent pancreatic normal tissues had no inflammation or tumor infiltration. These samples were used for validation studies. Patients' clinical features were recorded, including age of onset, gender, tumor location, tumor size, lymphatic metastasis, tumor differ- entiation, perineural invasiveness and TNM stage (according to UICC staging system, 2002).

2-DE. Pancreatic juice samples were applied to IPG (Immobilized pH gradient) strips (pi 4-7/17 cm), and hydration was performed for $14 \mathrm{~h}$ at $17^{\circ} \mathrm{C}$. Isoelectric focusing (IEF) was performed in a Protean IEF cell (Bio-Rad) at a starting voltage of $250 \mathrm{~V}$ for $30 \mathrm{~min}$. The voltage was then quickly increased to $1,000 \mathrm{~V}$ for $1 \mathrm{~h}$, followed by a linear increase to $10,000 \mathrm{~V}$ for $5 \mathrm{~h}$ and maintenance at $10,000 \mathrm{~V}$ until the total voltage and time cross product reached $60,000 \mathrm{~V} / \mathrm{h}$. Before carrying out the second-dimension with SDS-PAGE, the strips were subjected to a two-step equilibration, each of which was $15 \mathrm{~min}$ at room temperature. The first was performed in equilibration buffer consisting of $6 \mathrm{M}$ urea, $20 \%$ glycerol, $2 \% \mathrm{w} / \mathrm{v}$ SDS, $50 \mathrm{mM}$ Tris-HCl (pH 8.8), and 2\% (w/v) DTT. The second step was performed in the identical buffer, except that the DTT was replaced with $2.5 \% \mathrm{w} / \mathrm{v}$ iodoacetamide. After the IPG strips were transferred onto the seconddimension SDS-PAGE gel, the strips were fixed in place with $0.5 \% \mathrm{w} / \mathrm{v}$ agarose. SDS-PAGE was performed using $10 \%$ polyacrylamide gels $(180 \times 200 \times 1.5 \mathrm{~mm})$ in TGS buffer (BioRad) and Iso-Dalt gel tanks (Hoefer Scientific Instruments, San Francisco, CA), and the gels were run at $5 \mathrm{~mA} / \mathrm{gel}$ for $30 \mathrm{~min}$ and $20 \mathrm{~mA} /$ gel for $5.5 \mathrm{~h}$. After electrophoresis, the gels were stained using the silver-staining method by a Silver Stain kit (Bio-Rad) compatible with mass spectrometry (7).

Image analysis of two-dimensional gels. Integrated signal intensities were analyzed quantitatively using Bio-Rad 2-DE gel image analysis software (PDQuest7.4). The criterion for significant change in PC compared with $\mathrm{CP}$ and $\mathrm{CDS}$ was a 2-fold change in abundance.

$M A L D I-T O F / M S$. For each gel, seven differentially expressed protein spots were manually selected from the gels and subjected to MS protein identification. The spots were destained with $100 \mathrm{ml}$ of $30 \%$ acetonitrile in $50 \mathrm{mM}$ ammonium bicarbonate, washed in ultrapure water and dried in a SpeedVac evaporator. The dry gel pieces were digested with $10 \mathrm{ng} / \mathrm{ml}$ of trypsin (Promega) in $500 \mathrm{nM}$ ammonium bicarbonate at room temperature for $20 \mathrm{~h}$. The protein digests of each spot 
Table II. Primers used in this study.

\begin{tabular}{|c|c|c|c|c|c|}
\hline Method & Gene & & Primer sequences & $\begin{array}{c}\text { Annealing } \\
\text { temperature }\left({ }^{\circ} \mathrm{C}\right)\end{array}$ & $\begin{array}{l}\text { Product } \\
\text { size (bp) }\end{array}$ \\
\hline \multirow[t]{10}{*}{ RQ-PCR } & PRSS2 & Sense: & CAGCCGGACTCTGGACAATG & 60 & 72 \\
\hline & & Antisense: & GACACGCGGGAATTGATGAC & & \\
\hline & PLRP1 & Sense: & GTCTTCCCGCACTGTGTCTT & 60 & 107 \\
\hline & & Antisense: & TGATAAATCCAACССТCСCC & & \\
\hline & CTRB & Sense: & CCCACTGCGGGGTCAGGA & 60 & 280 \\
\hline & & Antisense: & GGGGTCTTGTTGGCGTTGTA & & \\
\hline & ELA3B & Sense: & AGTACGACCGTGCTGTGAAG & 60 & 210 \\
\hline & & Antisense: & CAGGGTGTCTCGTTGGGAAG & & \\
\hline & $18 \mathrm{~S}$ & Sense: & CTCTTAGCTGAGTGTCCCGC & 60 & 295 \\
\hline & & Antisense: & CTGATCGTCTTCGAACCTCC & & \\
\hline \multirow[t]{5}{*}{ MSP } & ELA3B & & & & \\
\hline & M & Sense: & AGTAGTTGGGGTTATAGGCGTTC & 55 & 119 \\
\hline & & Antisense: & AATAAATCACGAAATCAAAAA AT & & \\
\hline & $\mathrm{U}$ & Sense: & TGAGTAGTTGGGGTTATAGGT GTTT & 53 & 119 \\
\hline & & Antisense: & TAAATCACAAAATCAAAAAATCAAC & & \\
\hline
\end{tabular}

were extracted with $20 \mathrm{ml}$ of $0.1 \%$ TFA in $50 \%$ acetonitrile. Sample preparation for MS identification was performed with 384-spot Anchor targets, as indicated by the instrument's manufacturer (Bruker Daltonics, Bremen, Germany). Sample application was performed with a Cybio apparatus (Cybio, Jena, Germany). The samples were analyzed by MALDITOF-MS in a Bruker Autoflex mass spectrometer. Protein identification was conducted based on peptide mass fingerprinting (8). Peptide matching and protein searches were performed automatically using Mascot software (Roche, Basel). The National Center for Biotechnology Information non-redundant protein database was used. The peptide mass was compared with theoretical peptide masses of all available proteins from all species. Monoisotopic masses were utilized, and a mass tolerance of $0.0025 \%$ was allowed. Four matching peptides were the minimal requirement for an identity assignment. The algorithm used for determining the probability of a false positive match with a given MS spectrum is described elsewhere (9). Automatically identified sites were individually checked, and only human proteins were considered.

QRT-PCR validation in PC cell lines, PC tissues and their adjacent $P N$ tissues. Total RNA was extracted using TRIzol reagent (Invitrogen, Carlsbad, CA) according to the manufacturer's instructions. The RNA solution was treated with DNAse RQ1 (Promega, Madison, WI) to remove trace amounts of genomic DNA contamination. One microgram of RNA was converted to cDNA using the oligo(dT) primer system (Takara, Dalian, China) in a total volume of $50 \mu 1$. Aliquots of the reaction mixture were used for subsequent qPCR amplification with an ABI7500 (Applied Biosystems,
Foster City, CA) using SYBR Premix Ex Taq ${ }^{\mathrm{TM}}$ (Takara). The oligonucleotides used for gene-specific amplification are shown in Table II. Each experiment was performed in duplicate. The relative quantity (RQ) were determined using the $2^{(-\Delta \Delta C t)}$ method, with $18 \mathrm{~S}$ RNA used as a control. The PCR products were examined by gel electrophoresis.

Methylation-specific PCR (MSP) and bisulfite-sequencing $P C R(B S P)$. Bisulfite modification MSP was performed as described before (10). The promoter of $E L A 3 B$ gene was analyzed to find $\mathrm{CpG}$ islands and design MSP primers. The primers of MSP for ELA3B gene are shown in Table II. One microgram of genomic DNA was treated using EZ DNA Methylation kit (Zymo Research, Orange, CA, USA) according to the manufacturer's instructions. For MSP, $1 \mu 1$ modified DNA was amplified using MSP primers that specifically recognized the methylated or unmethylated DNA after bisulfite conversion. CpGenome Universal Methylated DNA (S7821) and CpGenome Universal Unmethylated DNA (s7822) (Chemicon Co., Temecula, CA, USA) were used as control for methylated and unmethylated DNA detection, respectively. Amplification products were visualized by UV illumination on 3\% low-range ultra-agarose gel (Bio-Rad Laboratories) that contained ethidium bromide. For quantitative MSP, the relative density of the amplified bands was measured by the ImageJ 1.38 software. The methylation index (MI) was calculated as follows: the relative density of the methylation amplified bands was divided by the sum of the methylated and the non-methylated bands.

5-aza-2'-deoxycytidine (5-Aza-dC) treatment. Cells were plated at a density of $3 \times 10^{4}$ cells $/ \mathrm{cm}^{2}$ in a 6 -well plate on 

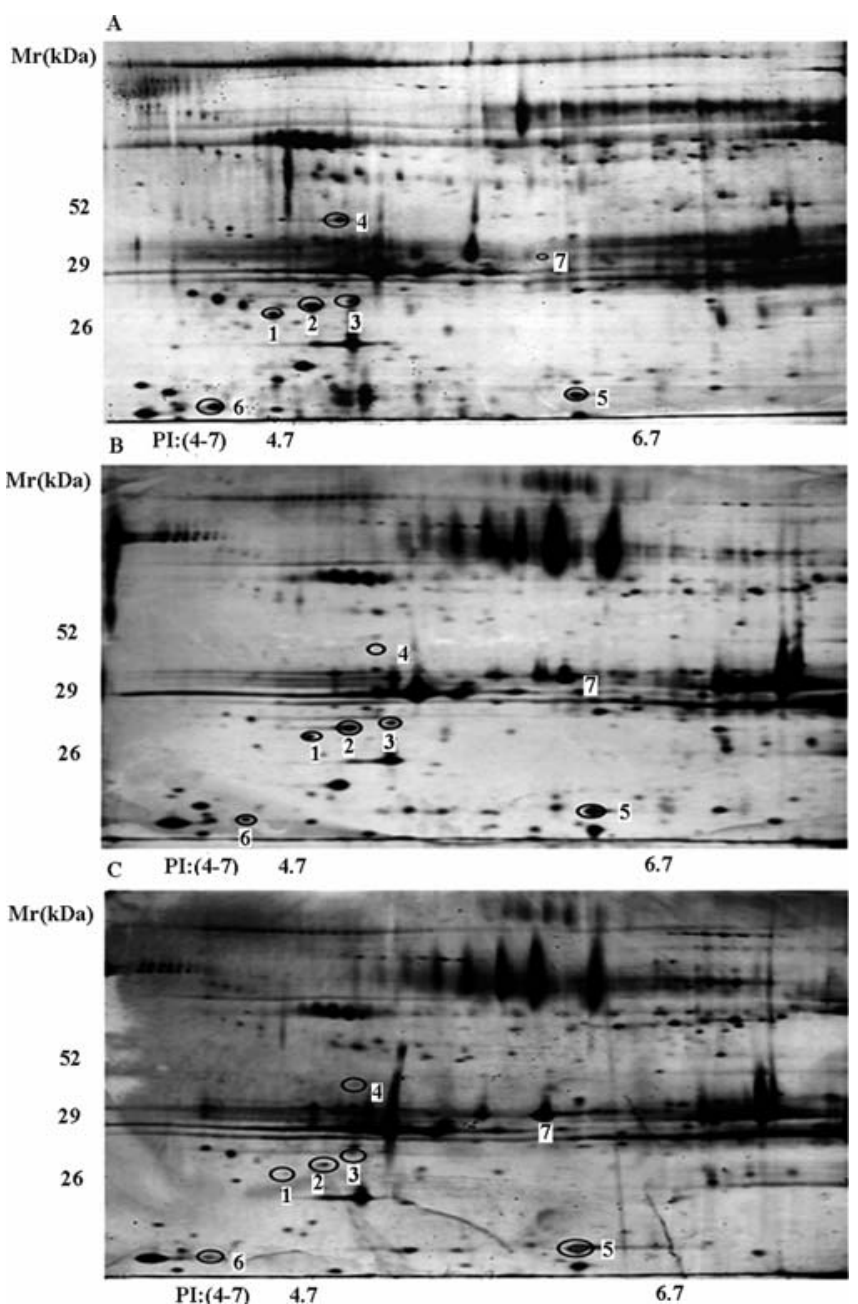

Figure 1. 2-DE patterns of total proteins obtained from pancreatic juice from patients. Proteins were separated in the first dimension on a $\mathrm{pH} \mathrm{4-7,17} \mathrm{cm}$ IPG strip. Two hundred micrograms of protein was loaded and a $20 \mathrm{~mA} / \mathrm{gel}$ second-dimension electrophoretic separation was performed for $5.5 \mathrm{~h}$. Seven of the proteins spots with at least 2-fold change in abundance in PC patients pancreatic juice were labeled with circles using image analysis software (PDQuest 7.4.0). PC (A), CP (B) and CDS (C).

day 0 . The demethylating agent 5-Aza-dC (Sigma-Aldrich, Deisenheim, Germany) was added on days 1, 2 and 3 to maintain its concentration at $5 \mu \mathrm{M}$ in fresh medium. Cells were harvested on day 4 for RNA and DNA extraction. Control cells were incubated without addition of 5-Aza-dC.

Statistical analysis. Significant differences of the mRNA RQ values for PRSS2 and ELA3B genes, and MI of ELA3B gene promoter from PC and PN tissues were determined by MannWhitney U test. The relation of PRSS2 and ELA3B mRNA RQ values (logarithmically transformed) with clinical characteristics were assessed by Student's t-test. Correlation of the RQ of ELA3B expression and its MI was determined by Spearman correlation analysis. Statistical analysis was processed by the SPSS 15.0 software package. P-values $<0.05$ were considered statistically significant.

\section{Results}

Identification of differential spots on 2-DE gels from pancreatic juice from patients. The pancreatic juice containing
$200 \mu \mathrm{g}$ total protein was separated by 2 -DE. The average numbers of protein spots of pooled PC, CP and CDS juice were $279 \pm 14,288 \pm 18$ and $272 \pm 11$, respectively. Seven protein spots which had 2-fold changes in PC compared to both $\mathrm{CP}$ and CDS using image analysis software were selected and analyzed by MALDI-TOF-MS (Fig. 1). Peptide mass and MASCOT searches identified four proteins, including two proteins up-regulated $>2$-fold, serine proteinase-2 (PRSS2) preproprotein and pancreatic lipase-related protein-1 (PLRP1), and two proteins down-regulated $>2$-fold, chymotrypsinogen $\mathrm{B}$ (CTRB) precursor and elastase 3B (ELA3B) preproprotein. PRSS2 preproprotein was identified from four 2-fold change spots. Quantitative comparisons and MS identification of the seven spots are shown in Fig. 2 and are summarized in Table III.

QRT-PCR in PC cell lines, PC tissues and PN tissues. To explore the origin of the up-regulated proteins observed in PC pancreatic juice, QRT-PCR was conducted to measure PRSS2, PLRP1, CTRB and ELA3B levels in PC cell lines, PC tissues and PN tissues. As shown in Fig. 3, RT-PCR tests showed that PRSS 2 mRNA was definitely highly expressed in all five PC cell lines, while PLRP 1 mRNA was detected in 4/5 cell lines (CFPAC, Panc-1, SW1990 and PaTu8988, but not BXPC3). ELA3B mRNA was undetectable in all cell lines, but CTRB mRNA was detected in 2/5 cell lines (SW1990 and PaTu8988). However, in PC tissues, PRSS2 mRNA levels were significantly higher $(\mathrm{P}<0.05, \mathrm{n}=30)$ compared to $\mathrm{PN}$, while there was no significant difference in PLRP1 mRNA levels detected in either PC or PN tissues. ELA3B mRNA levels were significantly higher $(\mathrm{P}<0.05$, $\mathrm{n}=30$ ) in PN tissues compared to the PC tissues, while CTRB mRNA levels were also detected in both of PC and PN tissues, but difference was not significant.

Relationship between mRNA levels of PRSS2 and ELA3B in $P C$ tissues and clinical characteristics. We analyzed statistically the relationship between the mRNA levels of PRSS2 and ELA3B in PC tissues and clinical features. As shown in Table IV, we found that the elevated expression of the PRSS2 gene was related with high T stage, while no correlation was found with other clinical features, including age of onset, gender, tumor location, tumor size, lymphatic metastasis, tumor differentiation, perineural invasiveness and TNM stage. These data suggested that elevated expression of the PRSS2 gene is an early event in PC tumorigenesis.

Methylation analysis. Because ELA3B gene expression was significantly lower in PC cell lines and tissues, we investigated its promoter hypermethylation status related to its low expression. The region of $5000 \mathrm{bp}$ around the transcript start site was selected for the CpG Island Searcher (http:// cpgislands.usc.edu/) with the criteria (GC content $>55 \%$, ObsCpG/Exp CpG >0.65 and length $=500$ bp). These criteria can effectively identify $\mathrm{CpG}$ islands associated with genes. We found a $\mathrm{CpG}$ island locating at -1351 to $-833 \mathrm{bp}$ (the transcriptional start site of ELA3B was designated as ' 0 '). Primers were designed to amplify the region -1042 to 933 bp containing two CpG sites (Table II). As shown in Fig. $4 \mathrm{~A}$ and $\mathrm{B}$, the promoter of ELA3B gene was hypermethylated in all five PC cell lines (Panc-1, PaTu8988, 


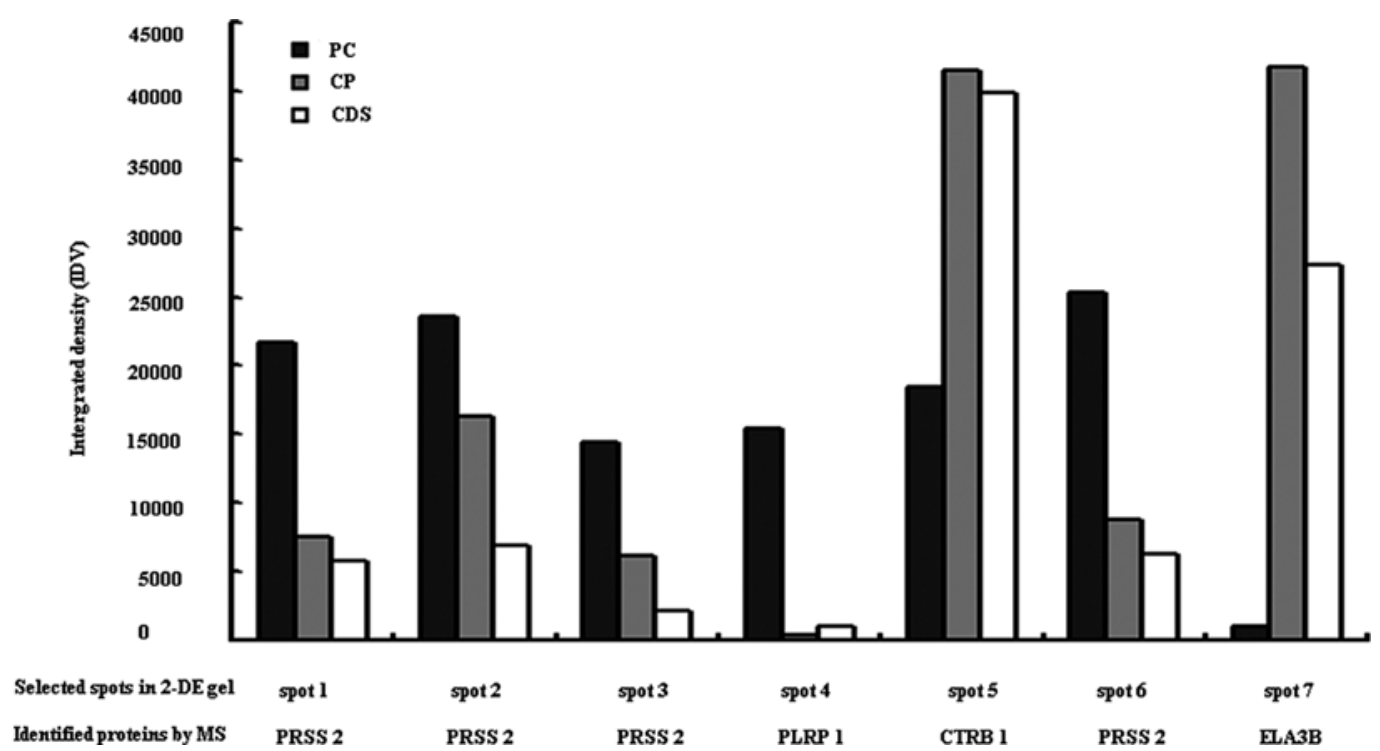

Figure 2. Quantitative comparisons of the seven significantly changed protein spots among the PC, CP and CDS groups. The volume of the spots was normalized and quantified as the relative intensity using PDQuest 7.4.0 software. The spot numbers indicated in this figure are the same as those in Fig. 1 and Table III.

Table III. Differential proteins identified by MALDI-TOF-MS.

\begin{tabular}{|c|c|c|c|c|c|c|c|}
\hline \multirow[b]{2}{*}{ Spot } & \multirow[b]{2}{*}{ Accession no./protein name } & \multirow{2}{*}{$\begin{array}{l}\text { Matched } \\
\text { peptides }^{\text {a }}\end{array}$} & \multirow{2}{*}{$\begin{array}{l}\text { Mascot } \\
\text { score }\end{array}$} & \multirow{2}{*}{$\begin{array}{c}\text { Sequence } \\
\text { coverage (\%) }\end{array}$} & \multirow[b]{2}{*}{ MW/PI } & \multicolumn{2}{|c|}{ Fold change $^{b}$} \\
\hline & & & & & & $\mathrm{PC} / \mathrm{CP}$ & $\mathrm{PC} / \mathrm{CDS}$ \\
\hline 1 & $\begin{array}{l}\text { gil } 4506147 / \text { serine } \\
\text { proteinase } 2 \text { preproprotein }\end{array}$ & $6 / 8$ & 84 & 25 & $26927 / 4.78$ & 2.86 & 3.75 \\
\hline 2 & $\begin{array}{l}\text { gil4506147/serine } \\
\text { proteinase } 2 \text { preproprotein }\end{array}$ & $6 / 8$ & 84 & 25 & $26927 / 4.78$ & 1.44 & 3.42 \\
\hline 3 & $\begin{array}{l}\text { gil } 4506147 / \text { serine } \\
\text { proteinase } 2 \text { preproprotein }\end{array}$ & $6 / 7$ & 91 & 28 & $26927 / 4.78$ & 2.36 & 6.66 \\
\hline 4 & $\begin{array}{l}\text { gil5453920/pancreatic } \\
\text { lipase-related protein } 1\end{array}$ & $7 / 22$ & 68 & 21 & $52556 / 5.47$ & 42.05 & 14.66 \\
\hline 5 & $\begin{array}{l}\text { gil117617/chymo- } \\
\text { trypsinogen B precursor }\end{array}$ & $6 / 12$ & 96 & 41 & $28479 / 6.79$ & 0.45 & 0.46 \\
\hline 6 & $\begin{array}{l}\text { gil4506147/serine } \\
\text { proteinase } 2 \text { preproprotein }\end{array}$ & $6 / 10$ & 81 & 40 & $26927 / 4.78$ & 2.90 & 4.05 \\
\hline 7 & $\begin{array}{l}\text { gil6679625/elastase 3B } \\
\text { preproprotein }\end{array}$ & $6 / 12$ & 89 & 21 & $29815 / 5.85$ & 0.02 & 0.04 \\
\hline
\end{tabular}

${ }^{a}$ Number of peptides matched/total peptides observed. ${ }^{b} \mathrm{PC} / \mathrm{CP}$ indicates the ratio of the relative intensity of spots in the pancreatic juice from patients with PC compared to CP. PC/CDS indicates the ratio of the relative intensity of spots in the pancreatic juice from patients with PC compared to CDS.

BXPC3, SW1990 and CFPAC), while the MI of ELA3B gene was significantly higher in PC tissues compared with PN tissues $(n=60, P=0.000)$. Linear correlation analysis showed that the extent of methylation of the ELA3B gene promoter negatively correlated with the mRNA levels $(\mathrm{n}=60$, Spearman's $r=-0.598, \mathrm{P}=0.000$ ) (Fig. 4C). Except the CFPAC cell line, the levels of ELA3B gene mRNA levels in the other PC cell lines were restored after 5-Aza-dC treatment (Fig. 4D), 

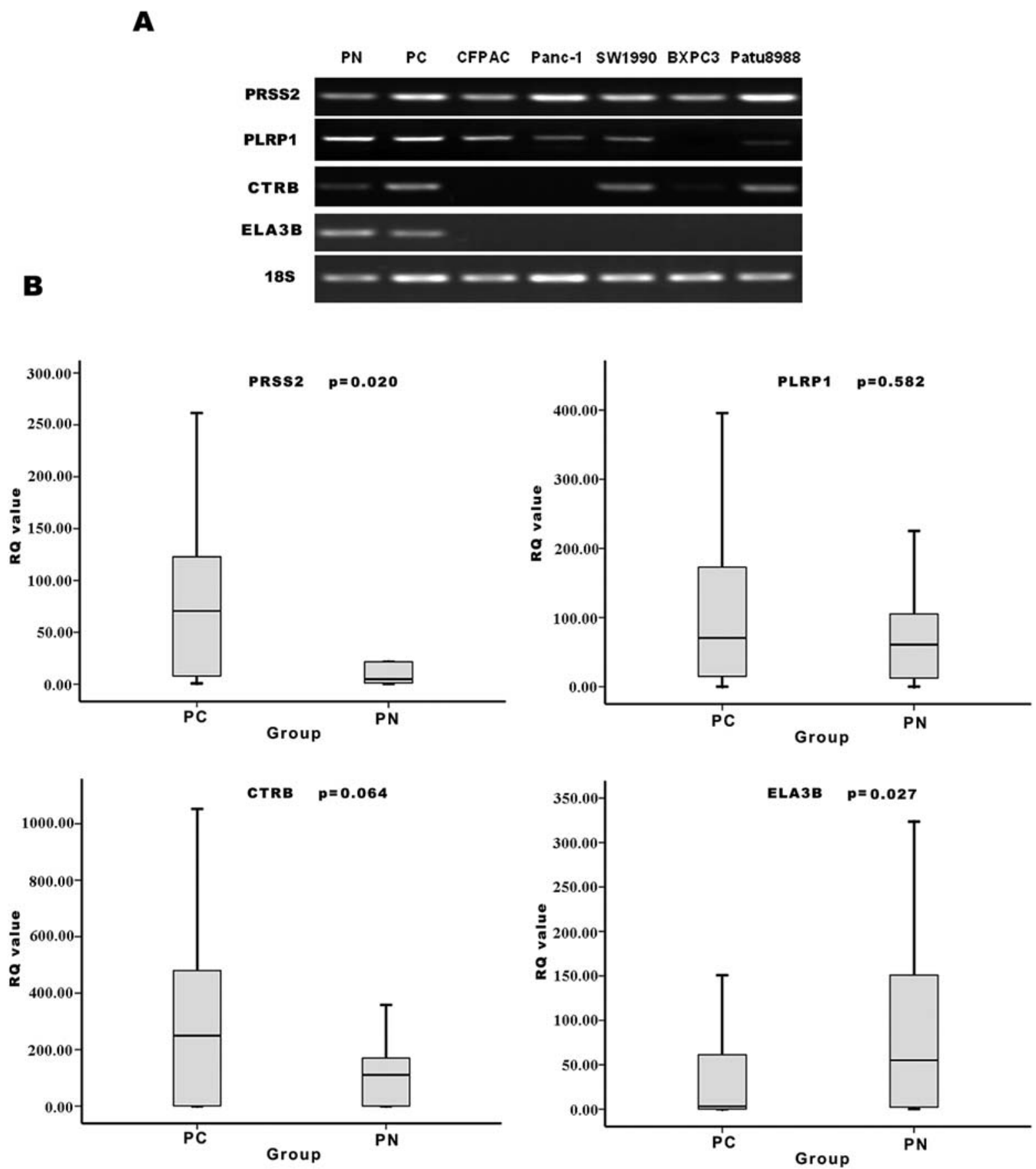

Figure 3. RT-PCR validation of protein abundance in PC cell lines and pancreatic tissues. (A) mRNA levels of PRSS2, PLRP-1, CTRB and ELA3B genes in PC cell lines. (B) The RQ value of PRSS2, PLRP-1, CTRB and ELA3B gene mRNA levels in PC tissues compared with PN tissues.

suggesting that methylation of the ELA3B gene promoter played a role in the down-regulation of its gene in the PC cell lines. These results show that hypermethylation of the ELA3B gene is a new type of PC-specific genetic biomarker.

\section{Discussion}

Cancer cells and their secreted proteins are preferentially shed into the ductal lumen, making the pancreatic juice a rich source of cancer-specific proteins. Analysis for pancreatic juice by $2-\mathrm{DE}$ is an effective method to find a $\mathrm{PC}$-specific marker.
In this study, we selected seven protein spots abundant in pancreatic juice of PC patient and identified them by MS. Four proteins (including PRSS2 preproprotein, PLRP1, CTRB precursor and ELA3B preproprotein) were found. Although these four proteins were reported in previous studies, some inconsistencies were found (Table V) (11-13). Some reasons that may account for these differences include the fact that pancreatic juice is highly complex and has a dynamic range of protein concentrations affected by gender, age, genetic factors, dietary, environmental and drug treatment. Another reason is that the current platform technologies cannot provide non-biased and complete protein identification and 
Table IV. Relation of PRSS2 and ELA3B levels in the pancreatic cancer tissues with clinical characteristics of pancreatic cancer patients.

\begin{tabular}{|c|c|c|c|c|c|}
\hline \multirow[b]{2}{*}{ Characteristics } & \multirow[b]{2}{*}{$\mathrm{N}$} & \multicolumn{2}{|c|}{ PRSS2 } & \multicolumn{2}{|c|}{ ELA3B } \\
\hline & & $\log _{10}(\mathrm{RQ}$-value $)$ & P-value & $\log _{10}($ RQ-value $)$ & P-value \\
\hline \multicolumn{6}{|l|}{ Age (years) } \\
\hline$<65$ & 21 & $1.42 \pm 0.76$ & 0.695 & $0.08 \pm 1.81$ & 0.454 \\
\hline$\geq 65$ & 9 & $1.55 \pm 0.85$ & & $0.98 \pm 0.89$ & \\
\hline \multicolumn{6}{|l|}{ Gender } \\
\hline Male & 15 & $1.24 \pm 0.85$ & 0.128 & $-0.29 \pm 1.44$ & 0.850 \\
\hline Female & 15 & $1.68 \pm 0.64$ & & $0.17 \pm 1.96$ & \\
\hline \multicolumn{6}{|l|}{ Tumor location } \\
\hline Head & 16 & $1.65 \pm 0.61$ & 0.155 & $0.78 \pm 1.32$ & 0.057 \\
\hline Body-tail & 14 & $1.25 \pm 0.90$ & & $-0.39 \pm 1.89$ & \\
\hline \multicolumn{6}{|l|}{ Tumor size $(\mathrm{cm})$} \\
\hline$<3$ & 13 & $1.25 \pm 0.68$ & 0.204 & $-0.01 \pm 1.50$ & 0.492 \\
\hline$\geq 3$ & 17 & $1.62 \pm 0.82$ & & $0.42 \pm 1.85$ & \\
\hline \multicolumn{6}{|c|}{ Lymphatic metastasis } \\
\hline Positive & 16 & $1.54 \pm 0.75$ & 0.555 & $0.28 \pm 1.62$ & 0.876 \\
\hline Negative & 14 & $1.37 \pm 0.82$ & & $0.18 \pm 1.83$ & \\
\hline \multicolumn{6}{|c|}{ Tumor differentiation } \\
\hline Poor & 11 & $1.54 \pm 0.78$ & 0.683 & $0.35 \pm 1.38$ & 0.767 \\
\hline Well & 19 & $1.42 \pm 0.79$ & & $0.16 \pm 1.89$ & \\
\hline \multicolumn{6}{|c|}{ Perineural invasiveness } \\
\hline+ & 16 & $1.29 \pm 0.85$ & 0.201 & $0.31 \pm 1.57$ & 0.790 \\
\hline- & 14 & $1.66 \pm 0.65$ & & $0.14 \pm 1.88$ & \\
\hline \multicolumn{6}{|l|}{ T stage } \\
\hline T0-2 & 19 & $1.19 \pm 0.80$ & $0.004^{\mathrm{a}}$ & $-0.17 \pm 1.62$ & 0.087 \\
\hline T3-4 & 11 & $1.92 \pm 0.48$ & & $0.93 \pm 1.65$ & \\
\hline \multicolumn{6}{|l|}{$\mathrm{N}$ stage } \\
\hline NO & 16 & $1.54 \pm 0.75$ & 0.555 & $0.28 \pm 1.63$ & 0.876 \\
\hline $\mathrm{N} 1$ & 14 & $1.37 \pm 0.82$ & & $0.18 \pm 1.83$ & \\
\hline
\end{tabular}

The RQ values of mRNA levels were logarithmically transformed and their relations with clinical characteristics were assessed by Student's

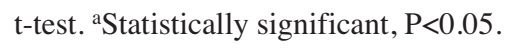

quantification in a complex biological sample (6). Furthermore, the control samples in different studies were obtained from different kinds of pancreatic disease. Thus, the identified proteins from PC patients by proteomics should be validated for their value in PC tissues and cells.

By RT-PCR, PRSS2 mRNA levels were significantly higher in PC cell lines and tissues compared with PN tissues. PRSS2 may play a key role in tumor invasion by degrading a wide spectrum of extracellular matrix proteins (14) and activating other proteinases, including MMPs 1, 2, 8, 9 and $13(15,16)$. PRSS2 has been reported to be highly expressed in several cancers, e.g., pancreatic (17), gastric (18), colorectal cancer (19), cholangiocarcinoma (20) and esophageal squamous cell carcinoma (21). The serum concentration of the inactive PRSS2 preproprotein was significantly higher in ovarian cancer patients with high stage compared to those with a low stage (22). Elevated serum levels of PRSS2 and PRSS2-API have been observed in a majority of patients with cholangiocarcinoma and pancreatic cancer (23). Based on the above mentioned reports and our results, PRSS2 may be a clinically useful biomarker for PC diagnosis and therapy.

A major advantage of the 2-DE-based method is its ability to separate intact isomeric forms or post-translational modified forms of a protein. An interesting finding of this study was that the up-regulated PRSS2 preproprotein was identified from 4 spots and demonstrated deviations between 


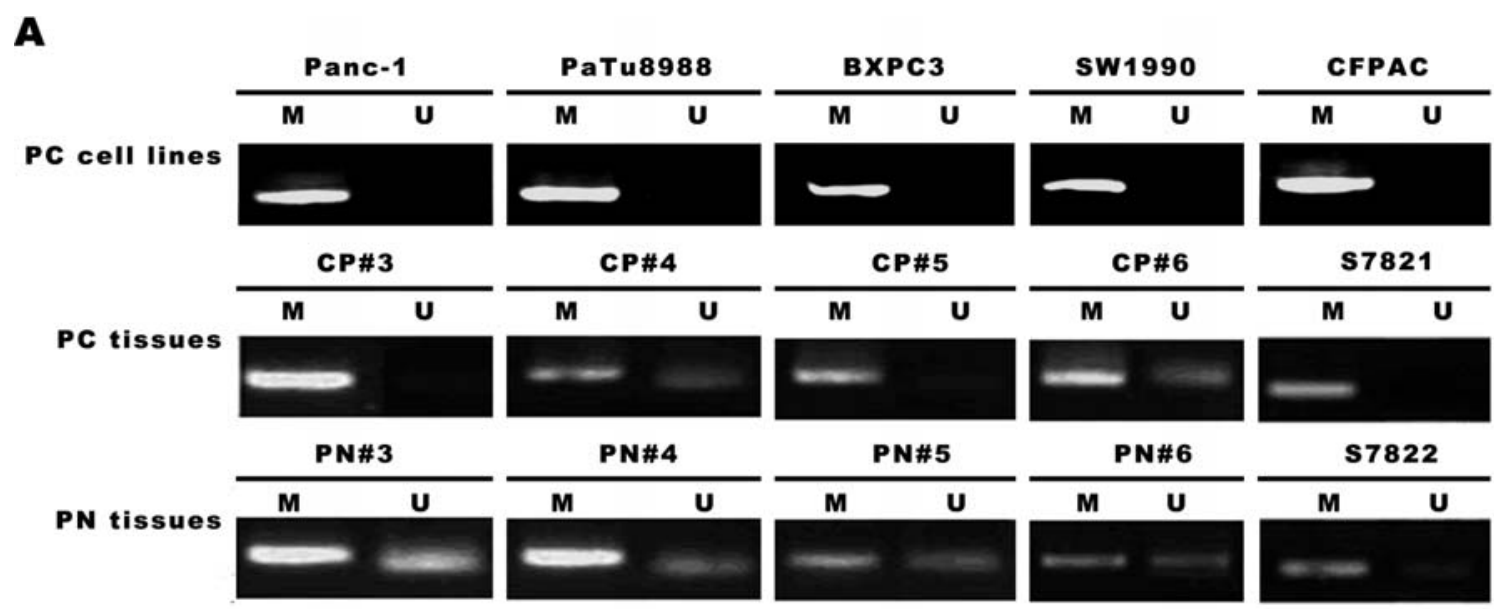

B

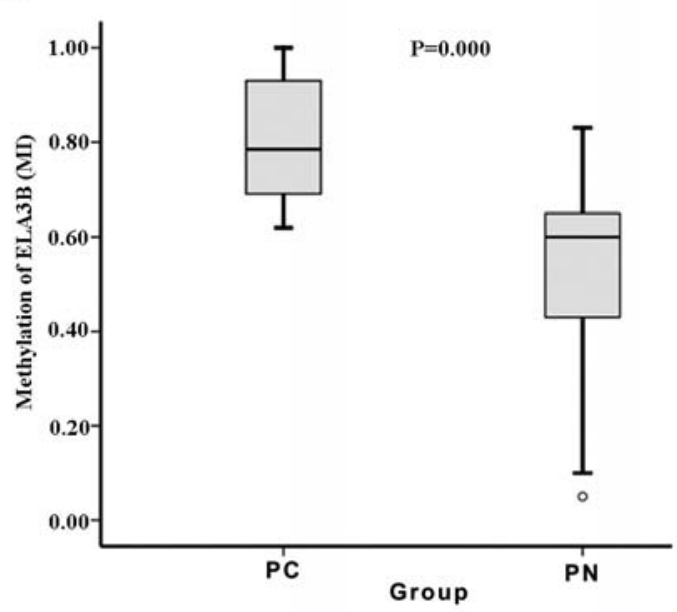

C

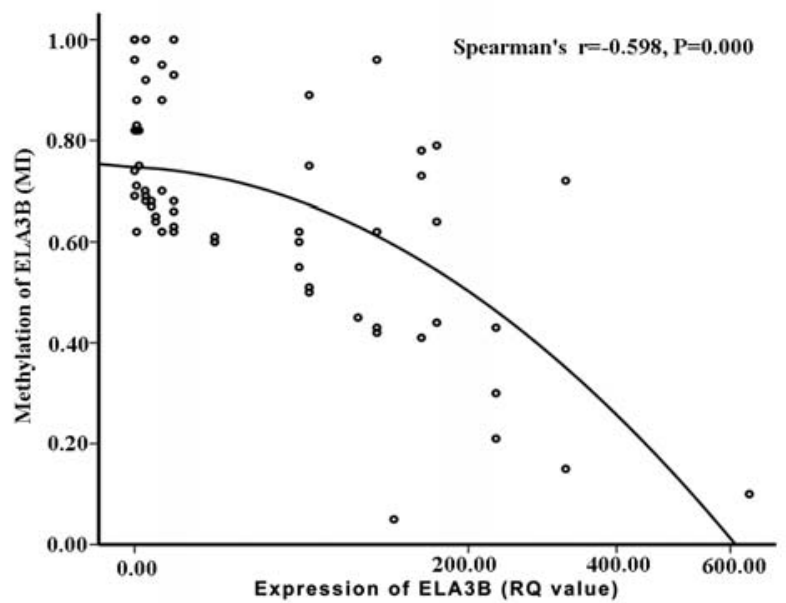

D

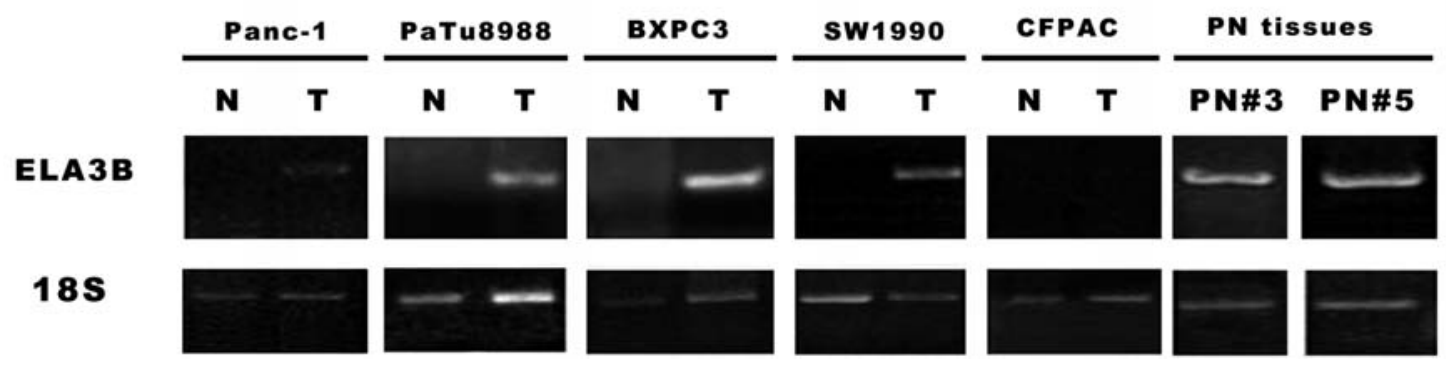

Figure 4. Methylation analysis of ELA3B gene promoter. (A) The methylation status of ELA3B gene promoter is shown in PC cell lines and parts of PC and their corresponding PN tissues. (B) Comparison of the MI difference of ELA3B gene promoter between PC and PN tissues. (C) Correlation of the RQ of ELA3B expression and its MI as determined by Spearman correlation analysis. (D) Changes in ELA3B gene expression in the PC cell lines treated by 5-Aza$\mathrm{dC}$ in vitro. $\mathrm{U}$, unmethylation; $\mathrm{M}$, methylation; $\mathrm{N}$, no treatment; $\mathrm{T}$, treatment.

its experimental and theoretical molecular weights and MW/ PI. Because these four spots appeared in all PC, CP and CDS gels, we propose that these isomeric forms are commonly present in the excreted juice. In addition, because all four spots were significantly up-regulated in PC, we propose that high levels of PRSS2 expression are a tumor-specific characteristic. Further research is needed to elucidate the role and function of PRSS2 isomeric forms in PC and other pancreatic diseases.

For the first time, we successfully demonstrated abnormal up-regulation of the PLRP-1 protein in pancreatic juice obtained from PC patients. Upon reviewing PubMed, we found two articles concerning the relationship between PLRP-1 and cancer. One article described work in which a sequence tag (ESTs) database from six different solid tumor types (breast, colon, lung, ovary, pancreas, and prostate) was expressed, and PLRP-1 showed a greater than 10-fold difference in PC libraries compared with normal tissuederived cDNA libraries (24). Another group used a cDNA microarray combined with RNA in situ hybridization in frozen ovarian cancer tissue (25). Although the PLRP-1 mRNA levels in PC tissues and PN tissues were not 
Table V. Proteins with at least 2-fold change in abundance in pancreatic juice from PC patients in the current study compared with other studies.

\begin{tabular}{lllll}
\hline Group & PRSS2 & PLRP-1 & CTRB & ELA3B \\
\hline Study 2 $(11,12)^{\mathrm{a}}$ & $\mathrm{Up}$ & No report & Up & Up \\
Study 1 $(13)^{\mathrm{b}}$ & No report & No report & Down & Down \\
Current study $^{\mathrm{c}}$ & $\mathrm{Up}$ & $\mathrm{Up}$ & Down & Down \\
\hline
\end{tabular}

${ }^{a}$ Control sample of the pooled juice (10 patients) from benign cystic neoplasm of pancreas and patients who were undergoing evaluation

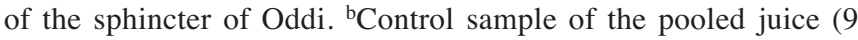
patients) from chronic pancreatitis (4), benign cystic neoplasm of pancreas (3), gallstone pancreatitis (1) and cystic fibrosis of pancreas (1). 'Control sample of both the pooled juice from chronic pancreatitis (10 patients) and the pooled juice from simple choledocholithiasis (6 patients).

significantly different, high PLRP-1 mRNA levels have been found in many PC cell lines (CFPAC, Panc-1, Sw1990 and PaTu8988), which suggested that PLRP1 might be a candidate marker in a subset of PC.

CTRB is a member of a family of serine proteases secreted into the gastrointestinal tract as inactive precursors which are activated by proteolytic cleavage by PRSS1. Some studies have found that CTRB levels were lower in pancreatic juice in PC, which is consistent with our 2-DE finding (Table V). Some reports have shown that levels of CTRB were low in PC tissues and some PC cell lines, but our validation tests showed that there was no significant difference of PLRP-1 gene mRNA levels in PC compared to PN tissue. CTRB mRNA was detected in some of PC cell lines (SW1990 and PaTu8988). In a previous study, it was shown that mRNA of CTRB gene could be detected in the peripheral blood of patients with pancreatic carcinoma as a genetic diagnostic marker (26). Further studies are needed to determine if the CTRB is a useful biomarker for PC.

ELA3B is a serine protease that hydrolyzes many proteins in addition to elastin. Humans have six elastase genes which encode structurally similar proteins elastase 1, 2, 2A, 2B, 3A and $3 \mathrm{~B}$. Unlike other elastases, ELA3B has little elastolytic activity. Like most of the human elastases, ELA3B is secreted from the pancreas as a zymogen and, like other serine proteases such as trypsin, chymotrypsin and kallikrein, it has a digestive function in the intestine. Excretion of ELA3B in fecal material is frequently used as a measure of pancreatic function in clinical assays. Some studies have found that ELA3B was lower in abundance in pancreatic juice in PC (13), which is consistent with our 2-DE finding (Table V). Some studies have found that ELA3B levels were low in PC tissues and some PC cell lines $(27,28)$, which also is consistent with our tests. Recently, many reports have proven that methylation of some genes involved in carcinogenesis can be biomarkers for cancer diagnosis and possible targets for treatment. So, we explored the methylation status of the ELA3B gene in PC cell lines and tissues. Our results showed hypermethylation of the ELA3B gene promoter in all five PC cell lines (Panc-1, PaTu8988, BXPC3, SW1990 and CFPAC) and PC tissues compared with PN tissues. The extent of methylation negatively correlated with its mRNA levels, suggesting that methylation of the ELA3B gene promoter is a potential new PC-specific genetic biomarker.

High expression of the PRSS2 gene and hypermethylation of ELA3B gene promoter are associated with PC, raising the possibility of their further application as new PC biomarkers in PC diagnosis and screening. Comparative proteomic analysis of pancreatic juice from PC patients is a powerful way to find new PC biomarkers.

\section{Acknowledgements}

The present study was supported by a grant of the National Natural Science Foundation of China (No.30370646) and the National Key Technology R\&D Program (No.2006BAI02A12). We thank Drs Zhengdong Jin, Chen Jie and Feng Liu at Changhai hospital of Second Military Medical University for the collection of pancreatic juice samples.

\section{References}

1. Michaud DS: Epidemiology of pancreatic cancer. Minerva Chir 59: 99-111, 2004.

2. Gao J, Li Z, Chen Z, Shao J, Zhang L, Xu G, Tu Z and Gong Y: Antisense Smo under the control of the PTCH1 promoter delivered by an adenoviral vector inhibits the growth of human pancreatic cancer. Gene Ther 13: 1587-1594, 2006.

3. Wang Y, Gao J, Li Z, Jin Z, Gong Y and Man X: Diagnostic value of mucins (MUC1, MUC2 and MUC5AC) expression profile in endoscopic ultrasound-guided fine-needle aspiration specimens of the pancreas. Int J Cancer 121: 2716-2722, 2007.

4. Shao J, Zhang L, Gao J, Li Z and Chen Z: Aberrant expression of PTCH (patched gene) and Smo (smoothened gene) in human pancreatic cancerous tissues and its association with hyperglycemia. Pancreas 33: 38-44, 2006.

5. Cho WC: Contribution of oncoproteomics to cancer biomarker discovery. Mol Cancer 6: 25, 2007.

6. Chen R, Pan S, Aebersold R and Brentnall TA: Proteomics studies of pancreatic cancer. Proteomics Clin Appl 1: 1582-1591, 2007.

7. Shevchenko A, Wilm M, Vorm O and Mann M: Mass spectrometric sequencing of proteins silver-stained polyacrylamide gels. Anal Chem 68: 850-858, 1996.

8. Henzel WJ, Billeci TM, Stults JT, Wong SC, Grimley C and Watanabe C: Identifying proteins from two-dimensional gels by molecular mass searching of peptide fragments in protein sequence databases. Proc Natl Acad Sci USA 90: 5011-5015, 1993.

9. Berndt P, Hobohm U and Langen H: Reliable automatic protein identification from matrix-assisted laser desorption/ionization mass spectrometric peptide fingerprints. Electrophoresis 20: 3521-3526, 1999.

10. Sasaki M, Anast J, Bassett W, Kawakami T, Sakuragi N and Dahiya R: Bisulfite conversion-specific and methylationspecific PCR: a sensitive technique for accurate evaluation of CpG methylation. Biochem Biophys Res Commun 309: 305-309, 2003.

11. Chen R, Pan S, Cooke K, Moyes KW, Bronner MP, Goodlett DR, Aebersold R and Brentnall TA: Comparison of pancreas juice proteins from cancer versus pancreatitis using quantitative proteomic analysis. Pancreas 34: 70-79, 2007.

12. Chen R, Pan S, Yi EC, Donohoe S, Bronner MP, Potter JD, Goodlett DR, Aebersold R and Brentnall TA: Quantitative proteomic profiling of pancreatic cancer juice. Proteomics 6: 3871-3879, 2006.

13. Tian M, Cui YZ, Song GH, Zong MJ, Zhou XY, Chen Y and Han JX: Proteomic analysis identifies MMP-9, DJ-1 and A1BG as overexpressed proteins in pancreatic juice from pancreatic ductal adenocarcinoma patients. BMC Cancer 8: 241, 2008. 
14. Koivunen E, Ristimaki A, Itkonen O, Osman S, Vuento M and Stenman UH: Tumor-associated trypsin participates in cancer cell-mediated degradation of extracellular matrix. Cancer Res 51: 2107-2112, 1991

15. Lukkonen A, Sorsa T, Salo T, Tervahartiala T, Koivunen E, Golub L, Simon S and Stenman UH: Down-regulation of trypsinogen-2 expression by chemically modified tetracyclines: association with reduced cancer cell migration. Int J Cancer 86: $577-581,2000$

16. Moilanen M, Sorsa T, Stenman M, Nyberg P, Lindy O, Vesterinen J, Paju A, Konttinen YT, Stenman UH and Salo T: Tumor-associated trypsinogen-2 (trypsinogen-2) activates procollagenases (MMP-1, -8, -13) and stromelysin-1 (MMP-3) and degrades type I collagen. Biochemistry 42: 5414-5420, 2003.

17. Ohta T, Terada T, Nagakawa T, Tajima H, Itoh H, Fonseca L and Miyazaki I: Pancreatic trypsinogen and cathepsin B in human pancreatic carcinomas and associated metastatic lesions. Br J Cancer 69:152-156, 1994.

18. Fujimura T, Ohta T, Kitagawa H, Fushida S, Nishimura GI, Yonemura Y, Elnemr A, Miwa K and Nakanuma Y: Trypsinogen expression and early detection for peritoneal dissemination in gastric cancer. J Surg Oncol 69: 71-75, 1998.

19. Williams SJ, Gotley DC and Antalis TM: Human trypsinogen in colorectal cancer. Int J Cancer 93: 67-73, 2001.

20. Terada T, Ohta T, Minato H and Nakanuma Y: Expression of pancreatic trypsinogen/trypsin and cathepsin B in human cholangiocarcinomas and hepatocellular carcinomas. Hum Pathol 26: 746-752, 1995.

21. Yamamoto H, Iku S, Itoh F, Tang X, Hosokawa M and Imai K: Association of trypsin expression with recurrence and poor prognosis in human esophageal squamous cell carcinoma. Cancer 91: 1324-1331, 2001
22. Paju A, Vartiainen J, Haglund C, Itkonen O, von Boguslawski K, Leminen A, Wahlstrom $\mathrm{T}$ and Stenman UH: Expression of trypsinogen-1, trypsinogen-2 and tumor-associated trypsin inhibitor in ovarian cancer: prognostic study on tissue and serum. Clin Cancer Res 10: 4761-4768, 2004.

23. Hedstrom J, Haglund C, Haapiainen R and Stenman UH: Serum trypsinogen-2 and trypsin-2-alpha(1)-antitrypsin complex in malignant and benign digestive-tract diseases. Preferential elevation in patients with cholangiocarcinomas. Int J Cancer 66: 326-331, 1996.

24. Scheurle D, De Young MP, Binninger DM, Page H, Jahanzeb M and Narayanan R: Cancer gene discovery using digital differential display. Cancer Res 60: 4037-4043, 2000.

25. Zheng M, Simon R, Kononen J, Sauter G, Mihatsch MJ and Moch H: Analysis of gene expression profiles among 3 epithelial ovarian tumor subtypes using cDNA and tissue microarrays. Ai Zheng 23: 771-776, 2004.

26. Kuroki T, Tomioka T, Tajima Y, Inoue K, Ikematsu Y, Ichinose K, Furui J and Kanematsu T: Detection of the pancreas-specific gene in the peripheral blood of patients with pancreatic carcinoma. Br J Cancer 81: 350-353, 1999.

27. Grutzmann R, Foerder M, Alldinger I, et al: Gene expression profiles of microdissected pancreatic ductal adenocarcinoma. Virchows Arch 443: 508-517, 2003.

28. Nakamura T, Fidler IJ and Coombes KR: Gene expression profile of metastatic human pancreatic cancer cells depends on the organ microenvironment. Cancer Res 67: 139-148, 2007. 